Catalysis Today 189 (2012) 70-76.

DOI: 10.1016/j.cattod.2012.03.053

\title{
Understanding the role of $\mathrm{C}_{3} \mathrm{H}_{6}, \mathrm{CO}$ and $\mathrm{H}_{2}$ on efficiency and selectivity of NOx Storage Reduction (NSR) process.
}

Liliana Masdrag ${ }^{1}$, Xavier Courtois $^{1 *}$, Fabien Can $^{1}$, Sébastien Royer $^{1}$, Emmanuel Rohart ${ }^{2}$, Gilbert Blanchard ${ }^{3}$, Patrice Marecot ${ }^{1}$, Daniel Duprez ${ }^{1}$

${ }^{1}$ Institut de Chimie des Milieux et des Matériaux de Poitiers (IC2MP), Université de PoitiersCNRS, 4 rue Michel Brunet, F-86022 Poitiers Cedex, France

${ }^{2}$ RHODIA Research \& Technologies, 52 rue de la Haie Coq, F-93308 Aubervilliers, France

${ }^{3}$ PSA, Peugeot Citroën, Route de Gisy, F-78943 Vélizy-Villacoublay Cedex, France

*Corresponding author, E-mail: xavier.courtois@univ-poitiers.fr

\begin{abstract}
The NOx storage reduction (NSR) process is commonly envisaged for the NOx treatment of exhaust gas from lean-burn engine vehicles. NOx are firstly stored on the catalyst, which is periodically submitted to a reducing mixture for few seconds in order to reduce the stored NOx into $\mathrm{N}_{2}$. The on-board reducer is coming from the gasoline/Diesel fuel and, in fact, the NSR catalyst is submitted to a mixture of hydrocarbons, $\mathrm{CO}$ and $\mathrm{H}_{2}$ with various compositions depending on the lean/rich step. In this study, the influence of each reducer $\left(\mathrm{C}_{3} \mathrm{H}_{6}, \mathrm{CO}\right.$ and $\left.\mathrm{H}_{2}\right)$ is evaluated separately, with a special consideration to the $\mathrm{N}_{2} \mathrm{O}$ selectivity. It is demonstrated that the $\mathrm{N}_{2} \mathrm{O}$ can be emitted during both lean and rich periods, with varying ratio depending on the considered reducer and the temperature of gas. For instance, at $300^{\circ} \mathrm{C}$, a high $\mathrm{N}_{2} \mathrm{O}$ selectivity is observed when $\mathrm{C}_{3} \mathrm{H}_{6}$ is used, and near half of the $\mathrm{N}_{2} \mathrm{O}$ emission occurs during the storage phase in lean condition.
\end{abstract}

Keywords: NOx, storage, reduction, NSR, selectivity, $\mathrm{N}_{2} \mathrm{O}$, ammonia, $\mathrm{NH}_{3}$. 


\section{Introduction}

One possible way to reduce NOx emissions from diesel and lean-burn engines is the use of a NOx storage reduction (NSR) catalyst [1]. It works mainly in lean condition. NOx are then oxidized on precious metals and stored on basic compounds, mainly as nitrates. Periodically, the catalyst is submitted to rich conditions for a few seconds and the stored NOx are reduced into $\mathrm{N}_{2}$ on the precious metals. Among the disadvantages of this system, the selectivity of the reduction may be problematic. Indeed, an incomplete reduction leads to the formation of $\mathrm{N}_{2} \mathrm{O}$, a powerful greenhouse gas. The $\mathrm{N}_{2} \mathrm{O}$ emission is usually observed at low temperatures (200$\left.300^{\circ} \mathrm{C}\right)$, whereas it tends to become zero at a higher temperature $\left(400^{\circ} \mathrm{C}\right)$. Another by product can also be observed when a high reduction level is achieved, namely $\mathrm{NH}_{3}$. Both $\mathrm{N}_{2} \mathrm{O}$ and $\mathrm{NH}_{3}$ production during the NSR process must obviously be proscribed.

Both $\mathrm{NH}_{3}$ and $\mathrm{N}_{2} \mathrm{O}$ can be observed during the NOx reduction $[2,3,4,5,6,7]$. Ammonia formation is favored when $\mathrm{H}_{2}$ is used as reducer [8,9] whereas $\mathrm{N}_{2} \mathrm{O}$ is obtained with $\mathrm{CO}$ as reducer $[4,10]$. In fact, the on-board reducer is coming from the gasoline/Diesel fuel and, the NSR catalyst is finally submitted to a mixture of hydrocarbons, $\mathrm{CO}$ and $\mathrm{H}_{2}$ with various compositions.

The objective of this work is to study the influence of the reducer on the selectivity of the NOx reduction during the NSR process, with a special consideration to the $\mathrm{N}_{2} \mathrm{O}$ selectivity. The examined reducers are $\mathrm{C}_{3} \mathrm{H}_{6}, \mathrm{CO}$ and $\mathrm{H}_{2}$. They were added separately in the rich pulses, as well as during the lean periods, in order to obtain a representative automotive exhaust gas. In this study, the catalyst was made of platinum (2.12\%) supported over a ceria-zirconia based oxide, with the aim to evaluate a rhodium free catalyst.

\section{Experimental part}

\subsection{Catalyst preparation}

The support used in this work is a ceria-zirconia based oxide provided by Rhodia. It would be denoted $\mathrm{CZ}$ in this study. Platinum $(2.12 \mathrm{wt} \%)$ was impregnated at $\mathrm{pH}=10$ using a $\operatorname{Pt}\left(\mathrm{NH}_{3}\right)_{2}\left(\mathrm{NO}_{2}\right)_{2}$ aqueous solution. After drying, the catalyst was pre-treated at $500^{\circ} \mathrm{C}$ for $4 \mathrm{~h}$ under synthetic air in order to stabilize Pt before the final hydrothermal treatment at $700^{\circ} \mathrm{C}$ for 25h (synthetic air and $10 \% \mathrm{H}_{2} \mathrm{O}$ ). The obtained catalyst is noted $\mathrm{Pt} / \mathrm{CZ}$ and exhibits $\mathrm{BET}$ specific surface area of $82 \mathrm{~m}^{2} \mathrm{~g}^{-1}$.

\subsection{Specific surface measurement}

The BET surface areas were deduced from $\mathrm{N}_{2}$ adsorption at $-196^{\circ} \mathrm{C}$ carried out with a 
Micromeritics apparatus. Prior to the measurement, the samples were treated at $250^{\circ} \mathrm{C}$ under vacuum for $8 \mathrm{~h}$ in order to eliminate the adsorbed species.

\subsection{XRD analysis}

$\mathrm{X}$-ray powder diffraction was performed at room temperature with a Bruker D5005 using a K $\alpha$ $\mathrm{Cu}$ radiation $(\lambda=1.54056 \AA$ ). The powder was deposited on a silicon monocrystal sample holder. The crystalline phases were identified by comparison with the ICDD database files.

\subsection{Hydrogen chemisorption}

Metal accessibility was determined on Pt/CZ catalyst with a Micromeritics AutoChem II instrument. Typically, $200 \mathrm{mg}$ of sample were reduced in hydrogen flowing $\left(30 \mathrm{~mL} \mathrm{~min}^{-1}\right)$ at $400^{\circ} \mathrm{C}$ for $1 \mathrm{~h}$, then purged in ultrapure $\operatorname{Ar}\left(30 \mathrm{~mL} \mathrm{~min}^{-1}\right)$ for $2 \mathrm{~h}$ and cooled down to room temperature. Pulses of $\mathrm{H}_{2}(0.5347 \mathrm{~mL})$ were injected at $-80^{\circ} \mathrm{C}$, every minute up to saturation (HC1). A new series of pulses was injected over the sample, after $10 \mathrm{~min}$ of purging under pure Ar, in order to determine the reversible part of the chemisorbed hydrogen (HC2). The irreversible part was taken as $\mathrm{HC}=\mathrm{HC} 1-\mathrm{HC} 2$.

\subsection{NOx storage capacity (NSC) measurement}

Before measurements, the catalyst (70mg) was firstly pretreated in situ for $15 \mathrm{~min}$ at $500^{\circ} \mathrm{C}$, under a $10 \% \mathrm{O}_{2}, 10 \% \mathrm{H}_{2} \mathrm{O}, 10 \% \mathrm{CO}_{2}$ and $\mathrm{N}_{2}$ mixture, and then cooled down to $400^{\circ} \mathrm{C}$ with the same mixture. The catalyst was then submitted to $4 \% \mathrm{CO}, 1.33 \% \mathrm{H}_{2}, 10 \% \mathrm{H}_{2} \mathrm{O}, 10 \% \mathrm{CO}_{2}$ and $\mathrm{N}_{2}$ for $15 \mathrm{~min}$ and cool down to $200^{\circ} \mathrm{C}$ under the same mixture. After a purge under $\mathrm{N}_{2}$, the sample was then submitted to 500ppm NO, $10 \% \mathrm{O}_{2}, 10 \% \mathrm{H}_{2} \mathrm{O}, 10 \% \mathrm{CO}_{2}$ and $\mathrm{N}_{2}$ mixture. For measurements at $300^{\circ} \mathrm{C}$ and $400^{\circ} \mathrm{C}$, the catalyst is treated in reducing mixture during the increase of the temperature. The total flow for the whole procedure is constant at $20 \mathrm{~L}^{-\mathrm{h}^{-1}}$. The gas flow was introduced using mass-flow controllers, except for $\mathrm{H}_{2} \mathrm{O}$ which was introduced using a saturator. Gas analysis $\left(\mathrm{NO}, \mathrm{NO}_{2}\right)$ was performed by a Multigas MKS 2030 analyzer (FTIR). Long time storage is not representative of the NSR catalyst working conditions, since the lean periods are commonly around $1 \mathrm{~min}$. The NOx storage capacity was then estimated by the integration of the recorded profile for the first 60 seconds, equal to the lean periods of the NSR test in cycling conditions (see below). The contribution of the reactor volume was subtracted. With the conditions used in this test, $99.2 \mu$ mol NOx per gram of catalyst were injected in 60s. The NOx storage fraction is then defined as follows:

NOx storage fraction $(\%)=100 x$ NOx stored $(\mu \mathrm{mol} / \mathrm{g}) / 99.2$

In addition, the platinum oxidation activity was estimated as the $\mathrm{NO}_{2} / \mathrm{NOx}$ ratio (\%) at 
saturation (usually after about 900s).

\subsection{NOx conversion in cycling conditions}

Before measurement, the catalyst $(70 \mathrm{mg})$ was treated in situ $15 \mathrm{~min}$ at $500^{\circ} \mathrm{C}$ under the full gas lean mixture, displayed on Table 1 . The sample was then cooled down to $200^{\circ} \mathrm{C}$ under the same mixture. The NOx conversion was studied in cycling condition by alternatively switching between lean (60s) and rich (4s) conditions using electro-valves. The lean and rich gas compositions are described in Table 1. Most gases ( $\mathrm{NO}, \mathrm{NO}_{2}, \mathrm{~N}_{2} \mathrm{O}, \mathrm{NH}_{3}, \mathrm{CO}, \mathrm{CO}_{2}, \mathrm{C}_{3} \mathrm{H}_{6} \ldots$ ) were analyzed using a Multigas FTIR detector (MKS 2030), except $\mathrm{H}_{2}$ which was analyzed by mass spectrometry. NOx reduction into $\mathrm{N}_{2}$ is calculated assuming no other $\mathrm{N}$-compounds than $\mathrm{NO}, \mathrm{NO}_{2}, \mathrm{~N}_{2} \mathrm{O}$ and $\mathrm{NH}_{3}$, neither $\mathrm{HNCO}$ which was never detected. For each tested temperature (200, 300 and $400^{\circ} \mathrm{C}$ ), the activity of the catalyst was followed until stabilization and calculations were done taking into account ten cycles after stabilization.

Supplementary tests were carried out with a simplified gas mixture, i.e. with only one reducing compound $\left(\mathrm{C}_{3} \mathrm{H}_{6}\right.$ or $\mathrm{CO}$ or $\left.\mathrm{H}_{2}\right)$, but with the same reducer/oxidant ratio as used with the complete gas mixture (Table 1). The reductant/oxidant ratio is calculated using equation (1), and corresponds to 0.017 and 3.35 for the lean and the rich gas mixture, respectively.

$$
\mathrm{red} / \mathrm{ox}=\left(9 *\left[\mathrm{C}_{3} \mathrm{H}_{6}\right]+[\mathrm{CO}]+\left[\mathrm{H}_{2}\right]\right) /\left([\mathrm{NO}]+2\left[\mathrm{O}_{2}\right]\right)
$$

Table 1: rich and lean gas compositions used for the NOx conversion test $(60 \mathrm{~s}$ lean $/ 4 \mathrm{~s}$ rich). Total flow rate: $20 \mathrm{~L} \mathrm{~h}^{-1}\left(\mathrm{SV}=200.000 \mathrm{~h}^{-1}\right)$. The redox ratio is constant at 0.017 at 3.35 in lean and rich gas mixture, respectively.

\begin{tabular}{|c|c|c|c|c|c|c|c|c|c|}
\hline \multirow{2}{*}{ Gas } & & \multicolumn{3}{|c|}{ Reducer } & \multicolumn{2}{|c|}{ Oxidant } & \multicolumn{3}{|c|}{ common gases } \\
\hline & & $\mathrm{C}_{3} \mathrm{H}_{6}$ & $\mathrm{CO}$ & $\mathrm{H}_{2}$ & $\mathrm{NO}$ & $\mathrm{O}_{2}$ & $\mathrm{CO}_{2}$ & $\mathrm{H}_{2} \mathrm{O}$ & $\mathrm{N}_{2}$ \\
\hline \multirow{4}{*}{ Full gas } & & 300 & 500 & 167 & 500 & 10 & \multirow{4}{*}{$\begin{array}{l}10 \\
\%\end{array}$} & \multirow{4}{*}{$\begin{array}{l}10 \\
\%\end{array}$} & \multirow{4}{*}{ balance } \\
\hline & Lean & ppm & ppm & ppm & ppm & $\%$ & & & \\
\hline & \multirow{2}{*}{ Rich } & 9000 & 4 & 1.33 & 100 & 2 & & & \\
\hline & & ppm & $\%$ & $\%$ & ppm & $\%$ & & & \\
\hline \multirow{4}{*}{$\begin{array}{l}\text { Only } \\
\mathrm{C}_{3} \mathrm{H}_{6} \\
\text { as reducer }\end{array}$} & \multirow{2}{*}{ Lean } & 374 & - & - & 500 & 10 & \multirow{4}{*}{$\begin{array}{l}10 \\
\%\end{array}$} & \multirow{4}{*}{$\begin{array}{l}10 \\
\%\end{array}$} & \multirow{4}{*}{ balance } \\
\hline & & ppm & - & - & ppm & $\%$ & & & \\
\hline & \multirow{2}{*}{ Rich } & 1.49 & & & 100 & 2 & & & \\
\hline & & $\%$ & - & - & $\mathrm{ppm}$ & $\%$ & & & \\
\hline \multirow{4}{*}{$\begin{array}{l}\text { Only } \\
\mathrm{CO} \\
\text { as reducer }\end{array}$} & \multirow{2}{*}{ Lean } & \multirow{2}{*}{-} & 3300 & - & 500 & 10 & \multirow{4}{*}{$\begin{array}{l}10 \\
\%\end{array}$} & \multirow{4}{*}{$\begin{array}{l}10 \\
\%\end{array}$} & \multirow{4}{*}{ balance } \\
\hline & & & ppm & - & ppm & $\%$ & & & \\
\hline & \multirow{2}{*}{ Rich } & \multirow{2}{*}{-} & 13.4 & 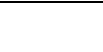 & 100 & 2 & & & \\
\hline & & & $\%$ & - & ppm & $\%$ & & & \\
\hline \multirow{4}{*}{$\begin{array}{l}\text { Only } \\
\mathrm{H}_{2} \\
\text { as reducer }\end{array}$} & \multirow{2}{*}{ Lean } & \multirow{2}{*}{ - } & \multirow{2}{*}{-} & 3300 & 500 & 10 & \multirow{4}{*}{$\begin{array}{l}10 \\
\%\end{array}$} & \multirow{4}{*}{$\begin{array}{l}10 \\
\%\end{array}$} & \multirow{4}{*}{ balance } \\
\hline & & & & ppm & ppm & $\%$ & & & \\
\hline & \multirow[t]{2}{*}{ Rich } & \multirow[t]{2}{*}{-} & \multirow{2}{*}{-} & 13.4 & 100 & 2 & & & \\
\hline & & & & $\%$ & ppm & $\%$ & & & \\
\hline
\end{tabular}




\subsection{Selective catalytic reduction (SCR) tests}

The SCR experiments were performed with various lean conditions as reported in Table 1. Before measurement, catalyst (70mg) was treated in situ $15 \mathrm{~min}$ at $500^{\circ} \mathrm{C}$ under the chosen lean mixture. The $\mathrm{N}$-compounds concentration $\left(\mathrm{NOx}, \mathrm{N}_{2} \mathrm{O}, \mathrm{NH}_{3}\right)$ were recorded from $500^{\circ} \mathrm{C}$ down to $200^{\circ} \mathrm{C}$ under the same mixture.

\section{Results and discussion}

\subsection{Chemical surface properties}

The chemical surface properties of catalysts were characterized using XRD analysis, BET surface area, $\mathrm{H}_{2}$-chemisorption and $\mathrm{H}_{2}$-TPR.

XRD patterns of the CZ support and the Pt-impregnated catalyst are reported in Figure 1.

XRD phase analysis of $\mathrm{CZ}$ mixed oxide shows the presence of only single phase solid solutions with a ceria cubic fluorite-like structure. In accordance with Damyanova and coll. [11], the main XRD peaks of mixed ceria-zirconia oxide are detected at $2 \theta=28.8,47.7$ and $56.5^{\circ}$. The average particle size deduced from the Scherrer equation is between 7.5 and $7.9 \mathrm{~nm}$, in agreement with ceria-zirconia oxides with similar specific surface areas [12].

The Pt impregnation step usually leads to barium leaching when $\mathrm{BaO} / \mathrm{Al}_{2} \mathrm{O}_{3}$ supports are used. XRD experiments show that $\mathrm{BaCO}_{3}$ and especially $\mathrm{BaAl}_{2} \mathrm{O}_{4}$ are significantly affected in aqueous media $[9,13]$. On the contrary, no change is observed by XRD analysis with the Pt/CZ catalyst, and no other diffraction peaks assigned to platinum or other compound is detected.

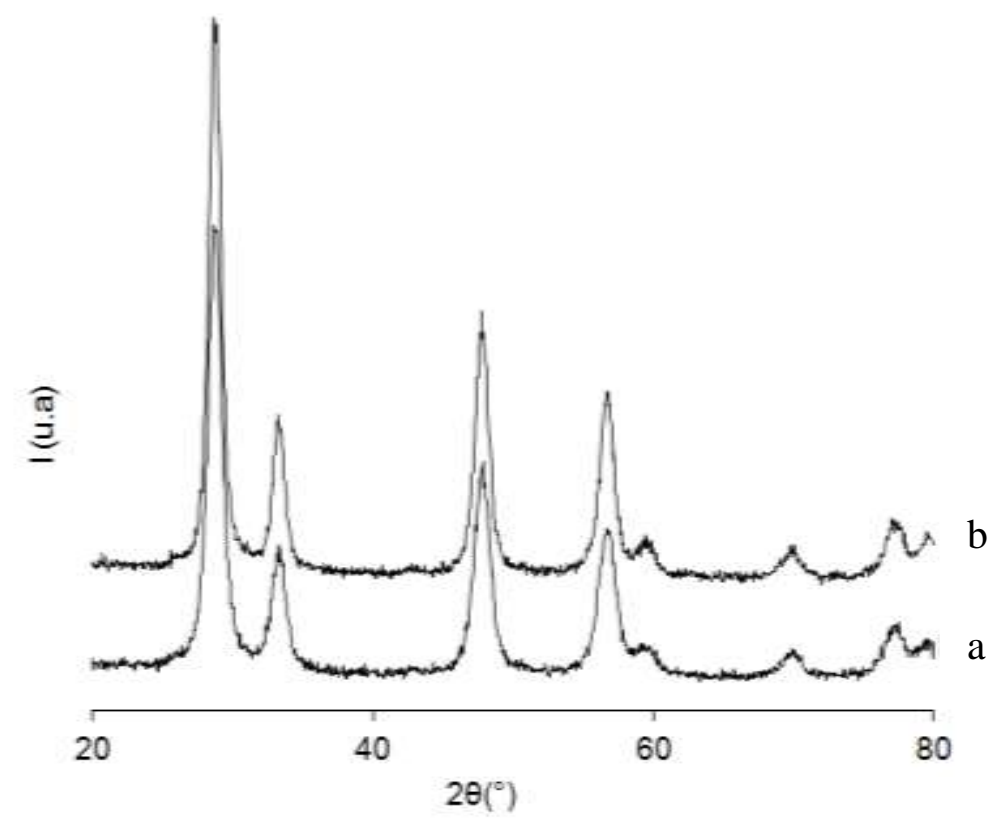

Figure 1: X ray diffractograms of $\mathrm{CZ}$ (a) and Pt/CZ (b) catalysts. 
Table 2: Specific surface area, Pt dispersion and hydrogen consumption measured from TPR experiments $\left(25-800^{\circ} \mathrm{C}\right.$ temperature range) for $\mathrm{CZ}$ and $\mathrm{Pt} / \mathrm{CZ}$ catalysts after hydrothermal treatment at $700^{\circ} \mathrm{C}$.

\begin{tabular}{lccc}
\hline Samples & $\begin{array}{c}\mathrm{S}_{\text {BET }} \\
\left(\mathrm{m}^{2} / \mathrm{g}\right)\end{array}$ & $\begin{array}{c}\mathrm{D} \\
(\%)\end{array}$ & $\begin{array}{c}\mathrm{H}_{2} \text { consumption (TPR) } \\
\left(\mu \mathrm{mol} \mathrm{H} / \mathrm{g}_{\text {cata. }}\right)\end{array}$ \\
\hline $\mathrm{CZ}$ & 116 & - & 858 \\
$\mathrm{Pt} / \mathrm{CZ}$ & 82 & $16 \%$ & 938 \\
\hline
\end{tabular}

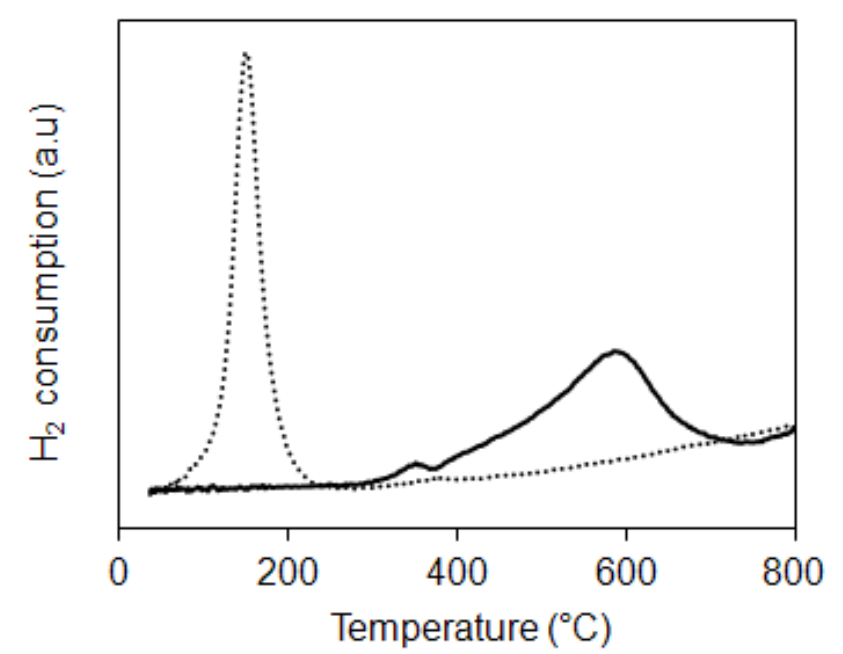

Figure 2: $\mathrm{H}_{2}$-TPR profiles of $\mathrm{CZ}$ (full line) and Pt/CZ (dotted line) samples.

Table 2 shows the BET surface area of the samples before and after the platinum impregnation step, and the platinum dispersion which was obtained by hydrogen chemisorption. Before platinum impregnation, the ceria-zirconia-based support exhibited a specific surface area of 116 $\mathrm{m}^{2} / \mathrm{g}$. A drop of $\mathrm{S}_{\mathrm{BET}}$ close to $30 \%$ is observed after Pt impregnation. From the hydrogen chemisorption measurement, the platinum dispersion is appraised to $16 \%$, which corresponds to particle size of $6.2 \mathrm{~nm}$.

Figure 2 displays the $\mathrm{H}_{2}$ temperature programmed reduction (TPR) profiles for $\mathrm{CZ}$ and $\mathrm{Pt} / \mathrm{CZ}$ samples. Concerning the support without metal, maximum hydrogen consumption is observed close to $600^{\circ} \mathrm{C}$, with a shoulder at much lower temperature $\left(380^{\circ} \mathrm{C}\right)$. The reducibility behaviors of ceria and ceria-zirconia mixed oxides have been extensively studied in the literature. As described by Yao et al. [14], the reduction of pure ceria typically occurs in two steps: bulk reduction occurs above $800-900^{\circ} \mathrm{C}$, while surface shell reduction step takes place at lower temperature $\left(400-550^{\circ} \mathrm{C}\right)$. With the incorporation of zirconia, a part of the bulk reduction occurs with the surface reduction step [15]. Depending on the $\mathrm{Zr}$ loading and the specific surface area, the reduction process of $\mathrm{CeO}_{2}-\mathrm{ZrO}_{2}$ mixed oxides split into two features, namely a low temperature step reduction $\left(400-600^{\circ} \mathrm{C}\right)$, and a higher temperature peak, around $900^{\circ} \mathrm{C}$ [16]. 
After platinum addition, a main reduction peak is observed at around $150^{\circ} \mathrm{C}$. It corresponds to the platinum reduction, but mainly to the easily reducible $\mathrm{Ce}^{\mathrm{IV}}$ reduction in $\mathrm{Ce}^{\mathrm{III}}$. In fact, addition of $2.12 \%$ of platinum facilitates the "surface" reduction step. However, the $\mathrm{H}_{2}$ consumption in the $25-800^{\circ} \mathrm{C}$ temperature range is not really affected by the platinum addition (table 2).

\subsection{NOx storage capacities (NSC)}

The NOx storage capacities were measured at 200,300 and $400^{\circ} \mathrm{C}$ in lean mixture containing $\mathrm{H}_{2} \mathrm{O}$ and $\mathrm{CO}_{2}$. The fractions of storage for 60 s are reported in Table 3, as well as the $\mathrm{NO}_{2} / \mathrm{NOx}$ ratio calculated at saturation.

The NOx storage capacity is rather limited, less than half of the introduced NOx for the first $60 \mathrm{~s}$ are trapped $(41-48 \%)$, with a maximum storage rate $300^{\circ} \mathrm{C}$. In the same time, the NO oxidation rate, estimated by the $\mathrm{NO}_{2} / \mathrm{NOx}$ ratio after saturation, also exhibits a maximum at $300^{\circ} \mathrm{C}$, at $64 \%$. It decreases to $54 \%$ at $400^{\circ} \mathrm{C}$ but it corresponds to the thermodynamic limitation at this temperature. These relatively high $\mathrm{NO}_{2} / \mathrm{NOx}$ ratios indicate that the storage may be limited by a lack of basic sites able to store NOx. Note that this catalyst is strongly dependant of a reducing pretreatment applied in this study before the NOx storage measurements. If the sample is not firstly submitted to a reducing atmosphere, the NO oxidation rate is strongly lower, especially at $200^{\circ} \mathrm{C}$, as already reported for ceria-zirconia oxides [15]. However, it was also showed that this low NO oxidation rate is partially compensated by the participation of the oxygen from the support in order to store NOx.

Table 3: Pt/CZ catalyst: percentage of stored NOx for 60s (NOx storage fraction; inlet: 500ppm NO, $10 \% \mathrm{O}_{2}, 10 \% \mathrm{H}_{2} \mathrm{O}, 10 \% \mathrm{CO}_{2}$ and $\mathrm{N}_{2}, 200 \mathrm{~mL} / \mathrm{min}$ ) and $\mathrm{NO}_{2} / \mathrm{NO}$ ratio after saturation.

\begin{tabular}{lccc}
\hline Temperature test & $200^{\circ} \mathrm{C}$ & $300^{\circ} \mathrm{C}$ & $400^{\circ} \mathrm{C}$ \\
\hline NOx storage fraction (\%) & 41 & 48 & 45 \\
\hline $\mathrm{NO}_{2} / \mathrm{NOx}(\%)$ & 41 & 64 & 54 \\
\hline
\end{tabular}

\subsection{NSR efficiency}

In the literature, the NOx storage-reduction efficiency is often discussed toward model $\mathrm{Pt} / \mathrm{BaAl}$ catalysts, or with simplified gas mixture. The particularity of this work is that reducers are also present in the lean mixture, as well as oxidant in the rich mixture (Table 1), awarding to this study applied conditions very close to the automotive exhaust gas. 


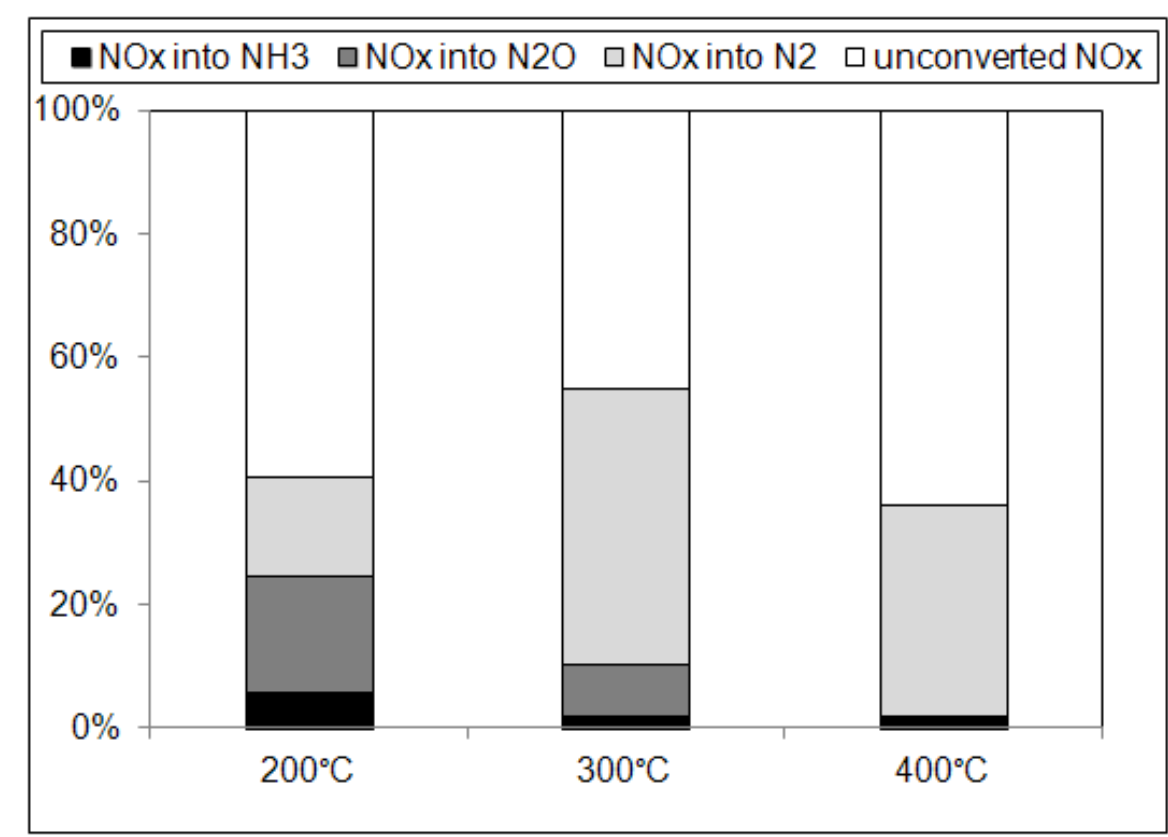

Figure 3: $\mathrm{Pt} / \mathrm{CZ}$ catalyst (70mg): NOx storage/reduction efficiency test at 200,300 and $400^{\circ} \mathrm{C}$ with $\mathrm{C}_{3} \mathrm{H}_{6}+\mathrm{CO}+\mathrm{H}_{2}$ reducers.

Results at $200^{\circ} \mathrm{C}, 300^{\circ} \mathrm{C}$ and $400^{\circ} \mathrm{C}$ (Figure 3) show that the NOx conversion depends on the temperature, with a maximum efficiency obtained at $300^{\circ} \mathrm{C}$. These results are consistent with the NOx storage fraction for 60s (Table 3), which reveals a higher amount of stored NOx at this temperature. NOx storage fraction and corresponding NOx reduction rate are rather close, contrary to previous results obtained with less complex mixtures, for which the NOx storage fraction was higher than the NOx reduction rate [9]. However, reactions involved in the NSR process with more complete mixtures are more complex than only storage during lean period and then reduction in rich condition. This point is discussed in section 3.5. Anyway, the observed NOx conversion is not selective into nitrogen, with significant emissions of $\mathrm{NH}_{3}$ and especially $\mathrm{N}_{2} \mathrm{O}$. These by-products yields decrease with temperature. In fact, the lower $\mathrm{N}_{2}$ selectivity is always obtained at $200^{\circ} \mathrm{C}$. Ammonia is supposed to be easily oxidized into $\mathrm{N}_{2}$, or it can be used for the NOx reduction in a second catalytic bed [17]. Finally, except for the higher temperature (i.e $400^{\circ} \mathrm{C}$ ), the main problematic by-product detected from this experiments remains $\mathrm{N}_{2} \mathrm{O}$, which is a powerful greenhouse gas (300 times more potent than $\mathrm{CO}_{2}$ ).

In the next part of this work, the NOx storage-reduction efficiency was firstly focused at $300^{\circ} \mathrm{C}$, with a special attention in the nature of reducers which should favor the $\mathrm{N}_{2} \mathrm{O}$ emission.

\subsection{Influence of reducer toward $\mathrm{N}_{2} \mathrm{O}$ emission}

In this section, the efficiency and the selectivity of the NSR catalyst was investigated using only one reducer (the same) in both lean and rich gas mixtures. For all the experiments, the 
reducer/oxidant ratio was kept constant and corresponds to 0.017 and 3.35 for lean and rich mixture, respectively. The concentration of each reducer $\left(\mathrm{C}_{3} \mathrm{H}_{6}, \mathrm{CO}\right.$ or $\left.\mathrm{H}_{2}\right)$ was adjusted consequently, as reported in Table 1. Results are presented in Figure 4.

$\boldsymbol{A}$

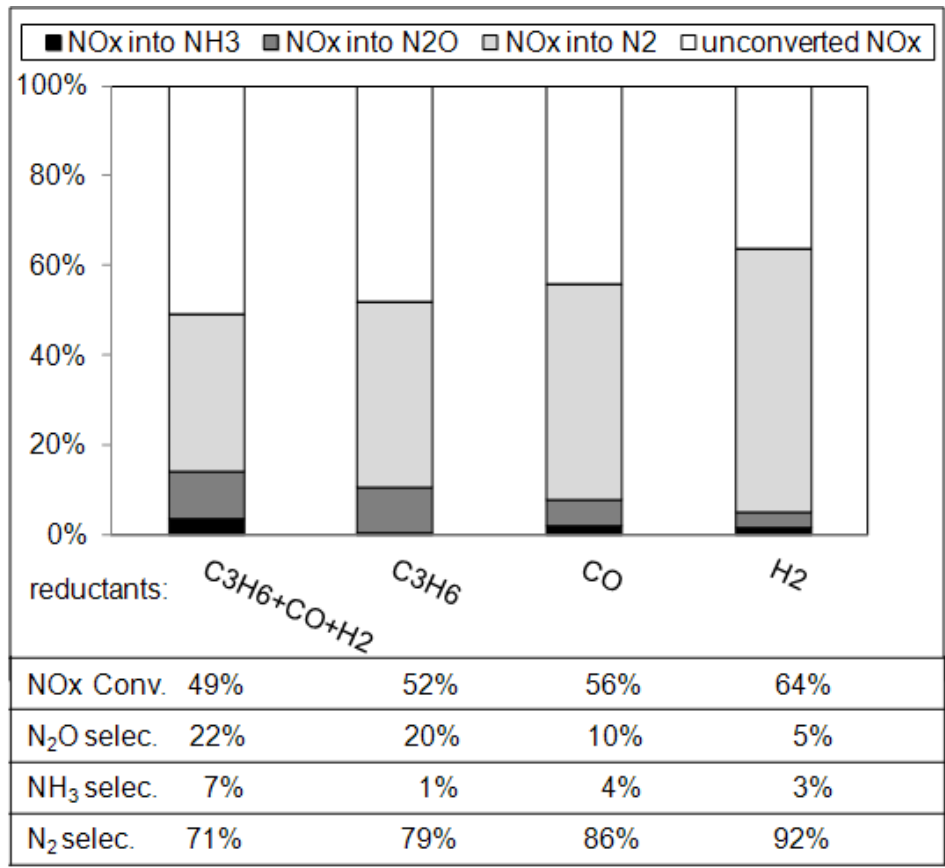

$\boldsymbol{B}$

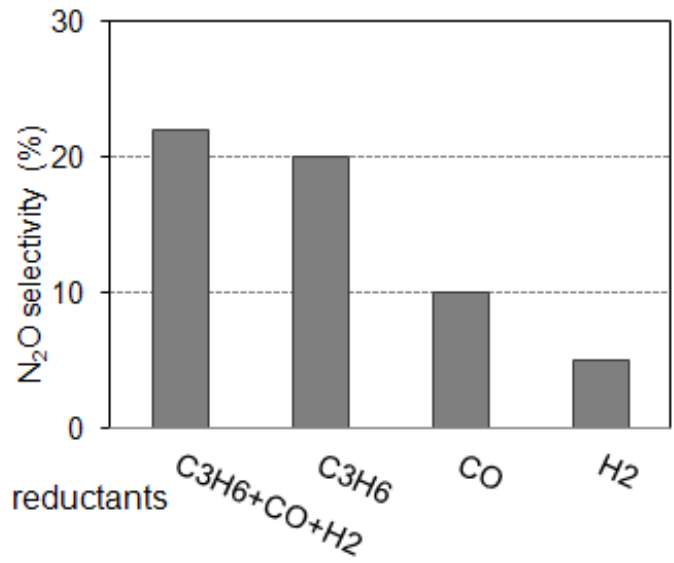

Figure 4: $\mathrm{Pt} / \mathrm{CZ}$ catalyst (70mg): NOx removal efficiency (A) and $\mathrm{N}_{2} \mathrm{O}$ selectivity (B) obtained at $300^{\circ} \mathrm{C}$ depending on the introduced reducer(s) (same in both lean and rich gas mixture).

As presented previously in Figure 3, with the whole of reducers $\left(\mathrm{C}_{3} \mathrm{H}_{6}+\mathrm{CO}+\mathrm{H}_{2}\right)$, the NOx conversion at $300^{\circ} \mathrm{C}$ is close to $50 \%$, with a high $\mathrm{N}_{2} \mathrm{O}$ selectivity (22\%). Ammonia is also detected ( $7 \%$ of selectivity). When only propylene is used as reducer (1.49\% and $374 \mathrm{ppm}$ in rich and lean periods, respectively), the NOx conversion remains nearly constant (Figure 4A), as well as the $\mathrm{N}_{2} \mathrm{O}$ selectivity. On the contrary, $\mathrm{NH}_{3}$ selectivity dramatically drops to $1 \%$. The ammonia selectivity reaches $4 \%$ and $3 \%$ with carbon monoxide or hydrogen as single reducer, respectively. In fact, the formation of ammonia is related to the presence of $\mathrm{H}_{2}$, which is also detected when $\mathrm{CO}$ is the only reducer. It was attributed to the water gas shift (WGS) reaction $\mathrm{CO}+\mathrm{H}_{2} \mathrm{O} \leftrightarrows \mathrm{CO}_{2}+\mathrm{H}_{2}$. Then, pulses of $\mathrm{H}_{2}$ are detected during the $\mathrm{CO}$ rich pulses, corresponding to an average $\mathrm{H}_{2}$ concentration of $2.37 \%$ during the rich pulses. Note that the reverse WGS also occurs when only $\mathrm{H}_{2}$ is introduced as reducer, leading to significant $\mathrm{CO}$ formation (average $\mathrm{CO}$ concentration: 202ppm, with maximum of 503ppm during the rich pulses). Finally, even if only $\mathrm{H}_{2}$ or $\mathrm{CO}$ is introduced, both $\mathrm{H}_{2}$ and $\mathrm{CO}$ are detected at $300^{\circ} \mathrm{C}$. In 
addition, thermodynamic calculations were performed at $300^{\circ} \mathrm{C}$ for WGS reaction equilibrium. Considering $10 \% \mathrm{H}_{2} \mathrm{O}, 10 \% \mathrm{CO}_{2}, 2 \% \mathrm{O}_{2}$ and $13.4 \% \mathrm{CO}$ as initial mixture, the thermodynamic equilibrium leads to concentrations of $1.7 \% \mathrm{CO}$ and $7.7 \% \mathrm{H}_{2}$. With $\mathrm{H}_{2}$ as reducer (13.4\%), $\mathrm{CO}$ and $\mathrm{H}_{2}$ concentrations at equilibrium $\left(300^{\circ} \mathrm{C}\right)$ are $0.15 \%$ and $9.25 \%$, respectively. However, the NOx conversion grows when $\mathrm{CO}$ and especially $\mathrm{H}_{2}$ are used as reducer (Figure 4A).

In addition to the WGS equilibrium, which influences the real reducing mixture, the steam reforming of $\mathrm{C}_{3} \mathrm{H}_{6}$ also occurs, but only from $300^{\circ} \mathrm{C}$. Indeed, using only $\mathrm{C}_{3} \mathrm{H}_{6}$ as reducer, emissions of $\mathrm{CH}_{4}, \mathrm{CO}$ and $\mathrm{H}_{2}$ are detected during the rich pulses. At $300^{\circ} \mathrm{C}$, taking into account the whole lean/rich cycles, the average concentrations for $\mathrm{CH}_{4}, \mathrm{CO}$ and $\mathrm{H}_{2}$ are $97 \mathrm{ppm}, 136 \mathrm{ppm}$ and $1.5 \%$, respectively. Using the $\mathrm{C}_{3} \mathrm{H}_{6}+\mathrm{CO}+\mathrm{H}_{2}$ mixture, the mean $\mathrm{CH}_{4}$ concentration reaches $66 \mathrm{ppm}$. Over emissions of $\mathrm{CO}$ and $\mathrm{H}_{2}$ are also detected, but they are not evaluable since both reducers are introduced in the inlet mixture, and they are supposed to be reactive. Finally, whatever the introduced reducer, $\mathrm{CO}$ and $\mathrm{H}_{2}$ are always detected at $300^{\circ} \mathrm{C}$. This can explain the possible formation of ammonia when only $\mathrm{C}_{3} \mathrm{H}_{6}$ is introduced as reducer.

The Figure $4 \mathrm{~B}$ reports the $\mathrm{N}_{2} \mathrm{O}$ selectivity function of the nature of the reducer used for the NOx reduction in cycling condition. It appears that $\mathrm{N}_{2} \mathrm{O}$ is detected whatever the nature of reducer. However, the main compound responsible for the $\mathrm{N}_{2} \mathrm{O}$ emission is clearly propylene. The $\mathrm{N}_{2} \mathrm{O}$ selectivity reaches $20 \%$, compared with $10 \%$ and $5 \%$ with $\mathrm{CO}$ and $\mathrm{H}_{2}$, respectively. Indeed, the $\mathrm{N}_{2} \mathrm{O}$ selectivity was evaluated in regard of the propylene concentration in the rich pulses (Figure 5). For these experiments, the amount of reducer in the rich gas mixture is balanced with hydrogen in order to keep the reducer/oxidant ratio constant. The lean period is composed of only propylene (374ppm), in order to have similar reducer in both mixtures. Figure 5 shows that $\mathrm{N}_{2} \mathrm{O}$ emission is clearly related with the propylene concentration in the rich pulses. However, when the rich gas composition does not contain propylene but hydrogen alone, the $\mathrm{N}_{2} \mathrm{O}$ selectivity is still quite high, with about $10 \%$. It is higher than the $5 \%$ previously observed when hydrogen is the only introduced reducer both in lean and rich mixtures (Figure 4). Similar experiments were thus performed without any reducers in the lean pulses. In this case, results presented in Table 4 show that the $\mathrm{N}_{2} \mathrm{O}$ emission in the global NSR cycles dramatically decreases from $10 \%$ to $4 \%$. It strongly suggests that NOx reduction also occurs during the lean period, leading to $\mathrm{N}_{2} \mathrm{O}$ formation. 


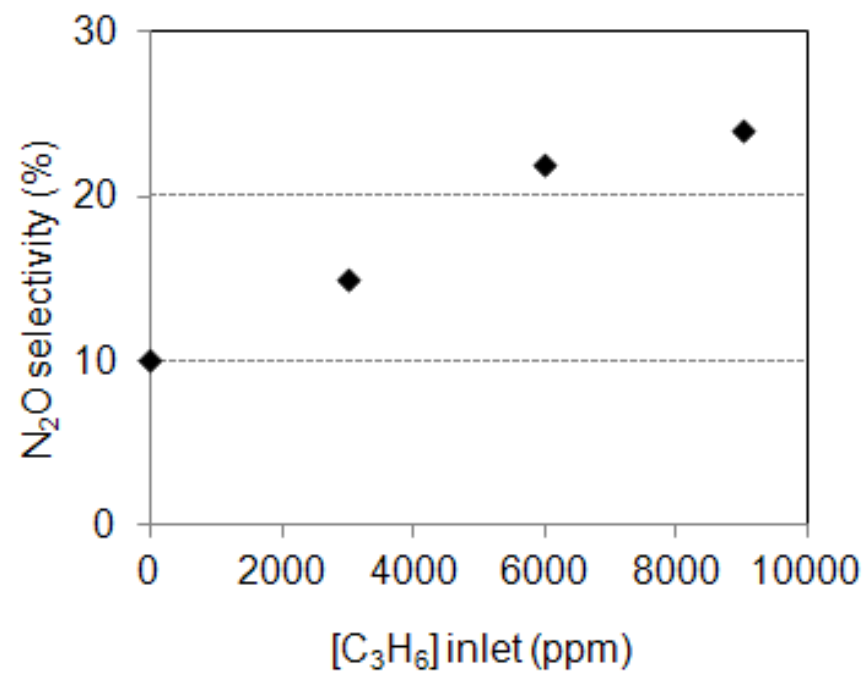

Figure 5: $\mathrm{Pt} / \mathrm{CZ}$ catalyst : $\mathrm{N}_{2} \mathrm{O}$ selectivity in function of propylene concentration in the rich pulses at $300^{\circ} \mathrm{C}$. The reducer/oxidant ratio was kept constant using $\mathrm{H}_{2}$.

Table 4: NOx storage-reduction efficiency and selectivity over $\mathrm{Pt} / \mathrm{CZ}$ using only $\mathrm{H}_{2}$ in the rich pulses: test with or without $\mathrm{C}_{3} \mathrm{H}_{6}$ in lean mixture.

\begin{tabular}{llcc}
\hline \multirow{2}{*}{ Introduced reducer } & Rich $(4 \mathrm{~s})$ & \multicolumn{2}{c}{$13 \% \mathrm{H}_{2}(\%)$} \\
\cline { 2 - 4 } & Lean $(60 \mathrm{~s})$ & $300 \mathrm{ppm}_{3} \mathrm{H}_{6}$ & $/$ \\
\hline \multirow{2}{*}{ NSR efficiency } & Selec. $\mathrm{N}_{2} \mathrm{O}(\%)$ & 10 & 4 \\
\hline
\end{tabular}

\subsection{Discussion}

Results presented previously indicate that $\mathrm{N}_{2} \mathrm{O}$ is also produced during the lean period. In the NSR process, the NOx storage phase has been studied extensively in the literature. But, as far as we known, the NOx reduction activity of NSR sample during the lean storage phase is not described. Some nitrous oxide formation recorded during NSR cycles experiments are detailed in Figure 6. Based on these results, the distribution of $\mathrm{N}_{2} \mathrm{O}$ formation during each gas mixture, namely lean and rich, has been evaluated at $300^{\circ} \mathrm{C}$ and reported in Table 5. Different behaviors are observed in function of reducer. When propylene is used as reducer, the $\mathrm{N}_{2} \mathrm{O}$ selectivity in NSR cycles reaches $20 \%$ at $300^{\circ} \mathrm{C}$ (Figure 4B) and it appears that around half of $\mathrm{N}_{2} \mathrm{O}$ is produced during the lean mixture (Table 5). Similar ratio is observed with $\mathrm{H}_{2}$ but the nitrous oxide selectivity during NSR cycles is only about $5 \%$ (Figure 4B). On the contrary, $90 \%$ of the $\mathrm{N}_{2} \mathrm{O}$ emission occurs during the rich pulses when carbon monoxide is the used as reducer (global $\mathrm{N}_{2} \mathrm{O}$ selectivity at around $10 \%$ ).

Finally, it appears that an important amount of $\mathrm{N}_{2} \mathrm{O}$ can be produced during the lean phase, depending on the nature of the reducer. To our knowledge, these observations are never discussed in the literature. In fact, usually, no reducers are present during the NOx storage phase. 
Table 5: Pt/CZ catalyst: distribution of $\mathrm{N}_{2} \mathrm{O}$ emission between lean and rich mixtures during the NSR cycles.

\begin{tabular}{lllll}
\hline & \multicolumn{2}{c}{$200^{\circ} \mathrm{C}$} & \multicolumn{2}{c}{$300^{\circ} \mathrm{C}$} \\
\hline $\mathrm{C}_{3} \mathrm{H}_{6}$ & Lean & Rich & Lean & Rich \\
\hline $\mathrm{CO}$ & $78 \%$ & $22 \%$ & $45 \%$ & $55 \%$ \\
\hline $\mathrm{H}_{2}$ & $13 \%$ & $87 \%$ & $10 \%$ & $90 \%$ \\
\hline
\end{tabular}

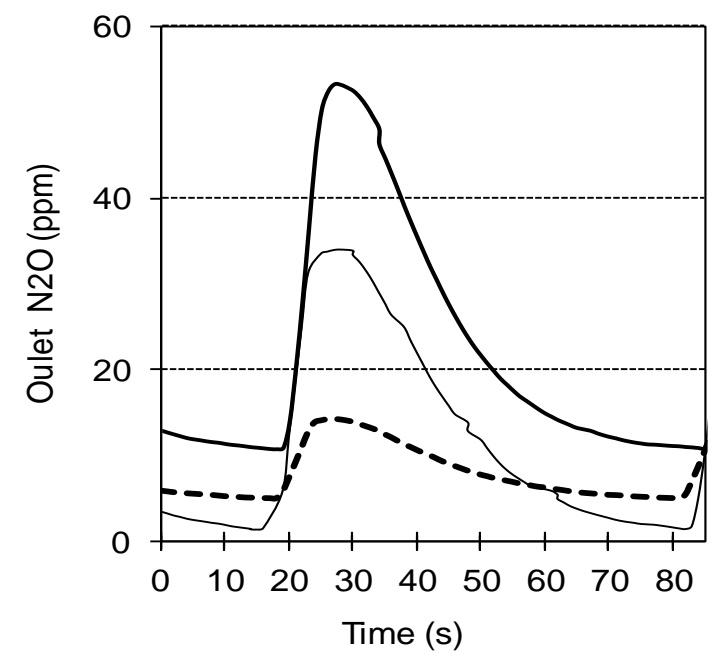

Figure 6: Pt/CZ catalyst: $\mathrm{N}_{2} \mathrm{O}$ profiles recorded during $\mathrm{NSR}$ cycles at $300^{\circ} \mathrm{C}$ with $\mathrm{C}_{3} \mathrm{H}_{6}(-)$ or $\mathrm{CO}(-)$ or $\mathrm{H}_{2}(\ldots$.$) as reducer.$
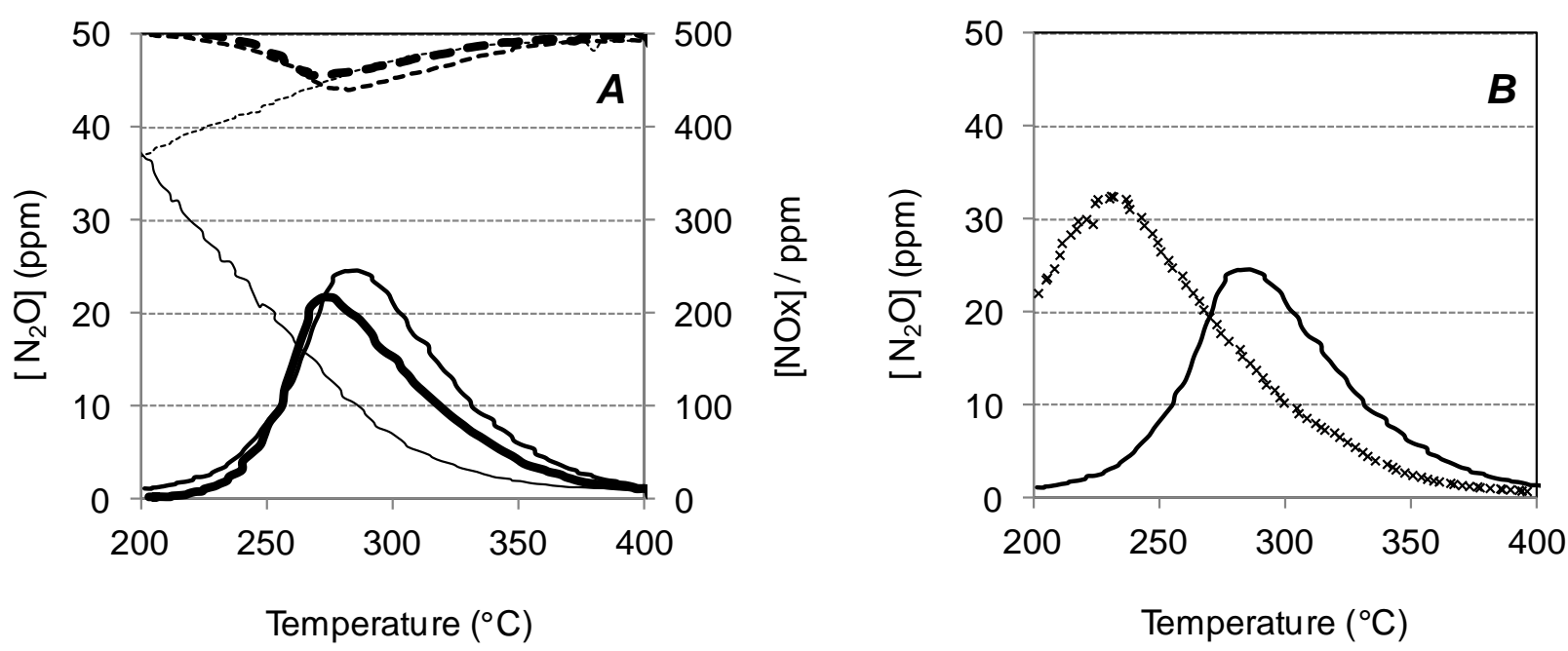

Figure 7: NOx reduction in lean mixture depending on the used reducer

(A) NOx conversion (dotted line) and $\mathrm{N}_{2} \mathrm{O}$ emission (full line) for:

$($ (, - . $):\left(500 p p m ~ N O+10 \% \mathrm{O}_{2}\right)+\left(300 \mathrm{ppm} \mathrm{C}_{3} \mathrm{H}_{6}+500 \mathrm{ppm} \mathrm{CO}+167 \mathrm{ppm} \mathrm{H}_{2}\right)$

$(\ldots, \ldots . . .):.\left(500 \mathrm{ppm} \mathrm{NO}+10 \% \mathrm{O}_{2}\right)+\left(3300 \mathrm{ppm} \mathrm{H}_{2}\right)$

$(-, \ldots .):.\left(500 \mathrm{ppm} \mathrm{NO}+10 \% \mathrm{O}_{2}\right)+\left(374 \mathrm{ppm} \mathrm{C}_{3} \mathrm{H}_{6}\right)$

(B) $\quad \mathrm{N}_{2} \mathrm{O}$ emission using (500ppm $\left.\mathrm{NO}+10 \% \mathrm{O}_{2}\right)+\left(374 \mathrm{ppm} \mathrm{C}_{3} \mathrm{H}_{6}\right)$ mixture

(-): fresh catalyst

$(\times \times \times)$ : catalyst previously tested in NSR cycled conditions at $400^{\circ} \mathrm{C}$ 
In order to obtain more information concerning the NOx conversion and the $\mathrm{N}_{2} \mathrm{O}$ formation during the lean phase, $\mathrm{Pt} / \mathrm{CZ}$ catalyst was tested using a selective catalytic reduction (SCR) type test. Experiments were performed using the same gas mixture than the lean gas compositions of the NSR test as reported in Table 1 (mixture of reducers, or each reducer separately). Firstly, near no NOx reduction is observed with $\mathrm{CO}$ as reducer, with a maximum of $2 \sim 3 \mathrm{ppm}$ of $\mathrm{N}_{2} \mathrm{O}$ emitted (results not shown), in accordance with Figure 6 and Table 5 which indicate nearly no $\mathrm{N}_{2} \mathrm{O}$ emission during the lean periods with this reducer. Results obtained with other reducers are reported in Figure 7A and show that the NOx conversion in excess of oxygen can be effective but depends on the temperature as well as the nature of reducer. With the whole reducers $\left(\mathrm{C}_{3} \mathrm{H}_{6}+\mathrm{CO}+\mathrm{H}_{2}\right)$, the NOx conversion reaches about $10 \%$ at $270^{\circ} \mathrm{C}$, corresponding to a maximum $\mathrm{N}_{2} \mathrm{O}$ emission of 22ppm (bold line, Figure 7A). Interestingly, when propylene is used as single reducer, results are very similar. The maximum NOx conversion (about 12\%) is then obtained at $283^{\circ} \mathrm{C}$, and $24 \mathrm{ppm}$ of $\mathrm{N}_{2} \mathrm{O}$ are emitted. These results are in accordance with the literature. For instance, Kotsifa et al. [18], have investigated the selective catalytic reduction of $\mathrm{NO}$ by propylene over platinum catalysts supported on various metal oxide supports $\left(\mathrm{Al}_{2} \mathrm{O}_{3}\right.$, $\left.\mathrm{CeO}_{2}, \mathrm{ZrO}_{2} \ldots\right)$. Authors concluded that the catalytic performance of catalyst may be improved by proper selection of the support. With alumina, $\mathrm{N}_{2}$ and $\mathrm{N}_{2} \mathrm{O}$ yields pass through maxima at $270^{\circ} \mathrm{C}$. Activities of $\mathrm{Pt} / \mathrm{CeO}_{2}$ catalysts are qualitatively similar to that supported on alumina, especially for the Tmax conversion (i.e $270^{\circ} \mathrm{C}$ ).

NOx conversion is likewise effective with $\mathrm{H}_{2}$ as reducer, but mainly at lower temperature. In fact, maximum NOx conversion is obtained at $200^{\circ} \mathrm{C}(27 \%)$, with the formation of about $37 \mathrm{ppm}$ of $\mathrm{N}_{2} \mathrm{O}$. Then, both $\mathrm{NOx}$ conversion and $\mathrm{N}_{2} \mathrm{O}$ concentration significantly decrease with temperature. Finally, note that ammonia emission is never observed in lean condition.

To conclude, the $\mathrm{N}_{2} \mathrm{O}$ formation in lean condition strongly depends on the nature of the reducer but also of the temperature. The SCR test shows that Pt/CZ catalyst is not efficient to reduce $\mathrm{NOx}$ by $\mathrm{CO}$ in excess of $\mathrm{O}_{2}$. In fact, the observed $\mathrm{N}_{2} \mathrm{O}$ selectivity is essentially due to the rich pulses, in accordance with results reported in Table 5. However, $\mathrm{H}_{2}$ and $\mathrm{C}_{3} \mathrm{H}_{6}$ exhibit very different behaviors depending on the temperature. Concerning $\mathrm{C}_{3} \mathrm{H}_{6}$, no $\mathrm{N}_{2} \mathrm{O}$ emission is observed at $200^{\circ} \mathrm{C}$ and $400^{\circ} \mathrm{C}$, and a maximum is observed at about $283^{\circ} \mathrm{C}$. On the contrary, hydrogen favors the nitrous oxide emission for the lower temperatures. These behaviors suggest different impact of each reducer on the $\mathrm{N}_{2} \mathrm{O}$ selectivity at $200^{\circ} \mathrm{C}$. Then, the influence of the nature of the reducer(s) was also studied at $200^{\circ} \mathrm{C}$. 


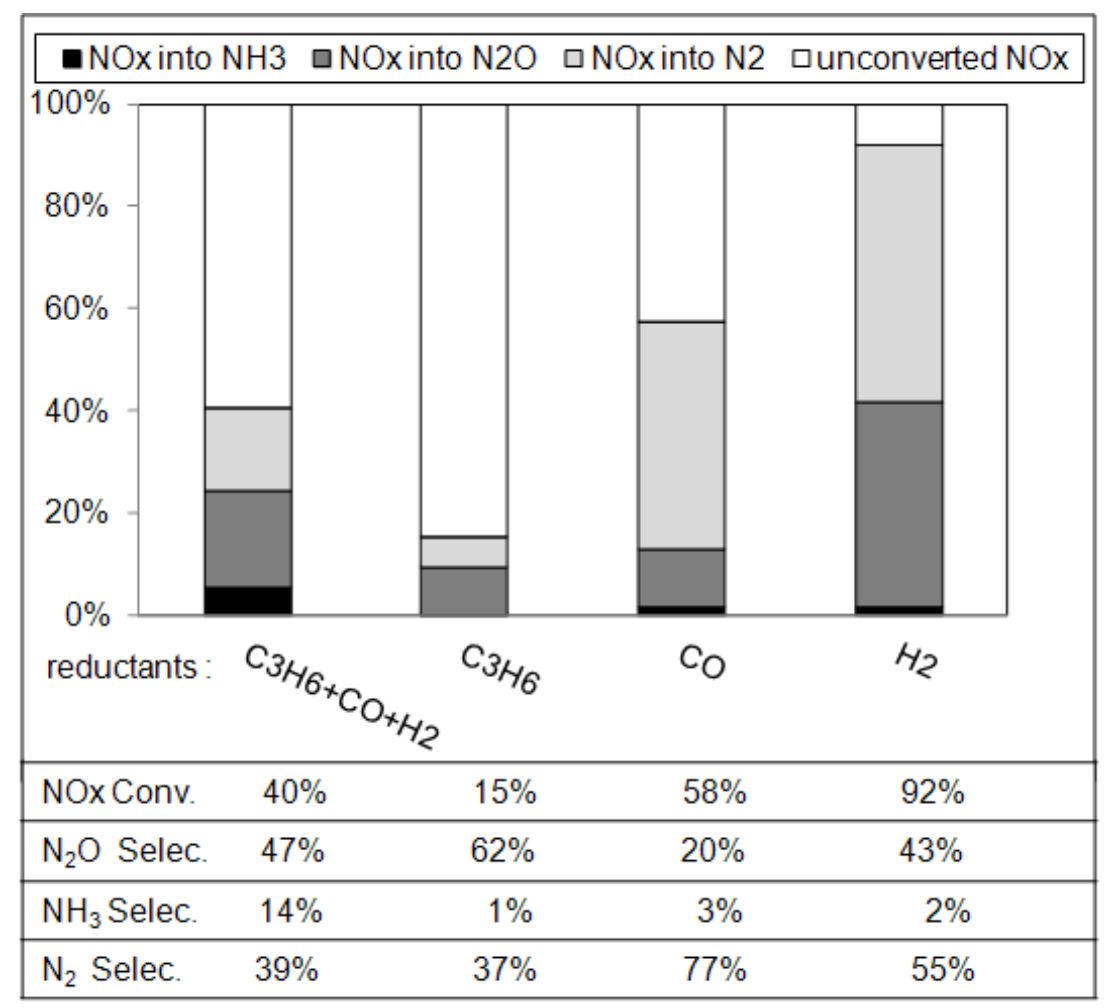

Figure 8: Pt/CZ catalyst (70mg): NOx removal efficiency obtained at $200^{\circ} \mathrm{C}$ depending on the introduced reducer(s) (same in both lean and rich gas mixtures).

Figure 8 reports the NOx efficiency, as well as the selectivity in nitrogen containing products at $200^{\circ} \mathrm{C}$, depending of the introduced reducer(s) for NSR experiments. It clearly appears that the higher NOx conversion, associated to the higher $\mathrm{N}_{2} \mathrm{O}$ emission, is observed with hydrogen. The global NOx conversion is thus about $92 \%$, and the corresponding selectivity into $\mathrm{N}_{2} \mathrm{O}$ reaches $43 \%$. As reported previously, the nitrous oxide formation is not only due to the NOx reduction which occurs during rich pulses. The distribution of $\mathrm{N}_{2} \mathrm{O}$ formation in each periods (i.e. lean and rich) is reported and Table 5. It confirms that the nitrous oxide formation is enhanced in the lean period with hydrogen at $200^{\circ} \mathrm{C}$, according with light-off curves reported in Figure 7.

As expected, using only $\mathrm{CO}$ as reducer, the lean periods do not significantly participate to the $\mathrm{N}_{2} \mathrm{O}$ emission. When only $\mathrm{C}_{3} \mathrm{H}_{6}$ is used, the NOx reduction rate is low at $200^{\circ} \mathrm{C}$, but the $\mathrm{N}_{2} \mathrm{O}$ selectivity is rather high. Quantification of the $\mathrm{N}_{2} \mathrm{O}$ emission during the rich and lean periods (Table 5) shows that a large amount of the $\mathrm{N}_{2} \mathrm{O}$ occurs during the lean phases, in opposition with the SCR profile reported in Figure 7. Actually, the catalyst behavior at $200^{\circ} \mathrm{C}$ is strongly dependant of the previous redox treatment, as previously mentioned in section 3.2 about the NOx storage measurement. In fact, $\mathrm{Pt} / \mathrm{CZ}$ is not active at $200^{\circ} \mathrm{C}$ in the NSR test if this 
measurement is carried out after the in situ pretreatment at $500^{\circ} \mathrm{C}$ for 15 min under the lean mixture (Table 1). On the contrary, NOx reduction activity is observed at $200^{\circ} \mathrm{C}$ if the catalyst is previously evaluated under redox cycles at 300 or $400^{\circ} \mathrm{C}$. In parallel, SCR test in lean mixture over $\mathrm{Pt} / \mathrm{CZ}$ catalyst previously submit to NSR tests at $400^{\circ} \mathrm{C}$ leads to a significant $\mathrm{NOx}$ reduction activity at $200^{\circ} \mathrm{C}$ (Figure $7 \mathrm{~B}$ ). The measured $\mathrm{N}_{2} \mathrm{O}$ concentration at $200^{\circ} \mathrm{C}$ is then consistent with that observed during the lean periods of the NSR test.

However, in opposition with results obtained at $300^{\circ} \mathrm{C}$ for which similar activities are obtained using $\mathrm{C}_{3} \mathrm{H}_{6}$ or mixture of $\mathrm{C}_{3} \mathrm{H}_{6}+\mathrm{CO}+\mathrm{H}_{2}$ (Figure $4 \mathrm{~A}$ ), results of NSR cycles reported in Figure 8 at $200^{\circ} \mathrm{C}$ with the whole reducers indicates that the influence of $\mathrm{C}_{3} \mathrm{H}_{6}$ is rather nil. It indicates that the adsorption competition between the three reducers strongly varies with the temperature. Propylene is the main active NOx reducer at $300^{\circ} \mathrm{C}$, whereas behavior at $200^{\circ} \mathrm{C}$ suggests the participation of the three reducers.

Finally, whatever the temperature $\left(200\right.$ or $\left.300^{\circ} \mathrm{C}\right)$, it is confirmed that the formation of $\mathrm{N}_{2} \mathrm{O}$ is enhanced by the presence of reducer during the lean periods, due to the NOx reduction activity in excess of oxygen. It depends of both on the temperature test and the nature of the reducer.

\section{Conclusion}

This study puts in evidence the possible problem of $\mathrm{N}_{2} \mathrm{O}$ emission during the NSR process. In fact, the production of $\mathrm{N}_{2} \mathrm{O}$ during the NSR cycles is function of both the used reducer(s) and the temperature test. Particularly, it appears in this study that presence of reducer in the lean gas mixture can lead to a competition between the NOx storage and the NOx reduction in excess of oxygen. Depending on temperature and reducer, near half of $\mathrm{N}_{2} \mathrm{O}$ can be produce during the lean periods, in accordance with results obtained during specific catalytic tests to study the NOx reduction in excess of $\mathrm{O}_{2}$ (SCR type tests). At $300^{\circ} \mathrm{C}$, the responsible for the $\mathrm{N}_{2} \mathrm{O}$ emission are $\mathrm{CO} \geq \mathrm{C}_{3} \mathrm{H}_{6}>\mathrm{H}_{2}$ for the rich periods, and $\mathrm{C}_{3} \mathrm{H}_{6}>\mathrm{H}_{2}>\mathrm{CO}(\approx 0)$ for the lean periods. The influence of the nature of the reducer is different at $200^{\circ} \mathrm{C}$ : $\mathrm{CO}>\mathrm{H}_{2} \geq \mathrm{C}_{3} \mathrm{H}_{6}$ for the rich periods, and $\mathrm{H}_{2}>\mathrm{CO} \geq \mathrm{C}_{3} \mathrm{H}_{6}(\approx 0)$ for the lean periods. However, the catalytic behavior at $200^{\circ} \mathrm{C}$ of the $\mathrm{Pt} / \mathrm{CZ}$ material strongly depends on the atmosphere pretreatment.

Finally, the nitrous oxide production at $200^{\circ} \mathrm{C}$ is mainly favored by hydrogen, whereas the most part the $\mathrm{N}_{2} \mathrm{O}$ emission at $300^{\circ} \mathrm{C}$ is attributed to propylene. These results point out the influence of complex gas mixtures on the catalytic behaviors. 
Acknowledgement

The Authors thank the French Ministry of Economy, Finance and Industry for its financial support (FUI contract $n^{\circ} 082906669$ NOSICA)

\section{References}

[1] T. Kobayashi, T. Yamada, K. Kayano, SAE Technical Papers 970745 (1997) 63.

[2] I. Nova, L. Lietti, L. Castoldi, E. Tronconi and P. Forzatti, J. Catal. 239 (2006), 244-254.

[3] Z. Liu and J.A. Anderson, J. Catal. 224 (2004) 18-27.

[4] H. Abdulhamid, E. Fridell, M. Skoglundh, Top. Catal. 30/31 (2004) 161-168.

[5] L. Castoldi, I. Nova, L. Lietti, P. Forzatti, Catal. Today 96 (2004) 43-52.

[6] I. Nova, L. Castoldi, L. Lietti, E. Tronconi, P. Forzatti, Catal. Today 75 (2002) 431-437.

[7] I. Nova, L. Lietti, P. Forzatti, Catal. Today 136 (2008) 128-135.

[8] N. Le Phuc, X. Courtois, F. Can, S. Berland, S. Royer, P. Marecot, D. Duprez, Catal. Today 176 (2011) 424-428.

[9] N. Le Phuc, X. Courtois, F. Can, S. Royer, P. Marecot, D. Duprez, Appl. Catal. B 102 (2011) 353-361.

[10] E.C. Corbos, M. Haneda, X. Courtois, P. Marecot, D. Duprez, H. Hamada, Appl. Catal. A 365 (2009) 187-193.

[11] S. Damyanova, C.A. Perez, M. Schmal, J.M.C. Bueno, Appl. Catal. A: Gen. 234 (2002) 271-282.

[12] N. Le Phuc, E.C. Corbos, X. Courtois, F. Can, P. Marecot, D. Duprez, Appl. Catal. B 93 (2009) 12-21

[13]G.W. Graham, H.W. Jen, H.W. Theis, R.W. McCabe, Catal. Lett. 93 (2004) 3-6.

[14] H.C. Yao, Y.F.Y. Yao, J. Catal. 86 (1984) 254-265.

[15] S. Overbury, D. Huntley, D. Mullins, G. Glavee, Catal. Lett. 51 (1998) 133-138

[16] F. Fally, V. Perrichon, H. Vidal, J. Kaspar, G. Blanco, J.M. Pintado, S. Bernal, G. Colon, M. Daturi, J.C. Lavalley, Catal. Today 59 (2000) 373-386

[17] T. Nakatsuji, M. Matsubara, J. Rouistenmaki, N. Sato, H. Ohno, Appl. Catal. B 77 (2007) 190-201

[18] A. Kotsifa, D.I. Kondarides, X. E. Verykios, Appl. Catal. B 80 (2008) 260-270 